Widiyanti et al., Afr., J. Infect. Dis. (2018) 12(S): 133-139

https://doi.org/10.2101/Ajid.v12i1S.20

\title{
EFFECT OF VARYING INCUBATION PERIODS ON CYTOTOXICITY AND VIRUCIDAL ACTIVITIES OF Justicia gendarussa Burm.f. LEAF EXTRACT ON HIV-INFECTED MOLT-4 CELLS
}

\author{
Prihartini Widiyanti ${ }^{1,2^{*}}$, Bambang Prajogo ${ }^{3}$, Agustinus Widodo ${ }^{4}$
}

${ }^{1}$ Faculty of Science and Technology, Airlangga University, Surabaya, Indonesia; ${ }^{2}$ Institute of Tropical Disease (ITD), Airlangga University, Surabaya, Indonesia; ${ }^{3}$ Department of Pharmacognosy, Faculty of Pharmacy, Airlangga University, Surabaya, Indonesia; ${ }^{4}$ Department of Pharmacy, Faculty of Mathematics and Natural Sciences, Tadulako University, Palu, Indonesia.

*Corresponding Author's E-mail: pwidiyanti@fst.unair.ac.id



\begin{abstract}
Backgrounds: Justicia gendarussa Burm.f. has an anti-HIV activity. This study was conducted to evaluate the effects of incubation periods on the cytotoxicity and virucidal activities of the J. gendarussa leaves extract on MOLT-4 cells.

Materials and Methods: The cytotoxicity assay was evaluated by using the WST-1 test with incubation periods of 3 days and 5 days. The virucidal activity test was determined by measuring the inhibitory activities on the syncytium formation.

Results: The cytotoxicity assay showed the value of $\mathrm{CC}_{50}$ on MOLT-4 cell culture with the test material of $70 \%$ ethanol extract of $J$. gendarussa leaves as much as $3928.620 \mu \mathrm{g} / \mathrm{mL}$ and $3176.581 \mu \mathrm{g} / \mathrm{mL}$ (incubation day 3 and day 5 , respectively); fractionated-70\% ethanol extract $=81782.428 \mu \mathrm{g} / \mathrm{mL}$ and $12175.870 \mu \mathrm{g} / \mathrm{mL}$; and water extract $=$ $16372.689 \mu \mathrm{g} / \mathrm{mL}$ and $2946.117 \mu \mathrm{g} / \mathrm{mL}$. The test results of the virucidal activities (inhibit $\geq 90 \%$ the formation of syncytium) of $70 \%$ ethanol extract of $J$. gendarussa leaves is at a concentration $250 \mu \mathrm{g} / \mathrm{mL}, 500 \mu \mathrm{g} / \mathrm{mL}$ and 1000 $\mu \mathrm{g} / \mathrm{mL}$ (3-day incubation) and $250 \mu \mathrm{g} / \mathrm{mL}$ (5-day incubation); and fractionated-70\% ethanol extract at a concentration $250 \mu \mathrm{g} / \mathrm{mL}, 500 \mu \mathrm{g} / \mathrm{mL}$ and $1000 \mu \mathrm{g} / \mathrm{mL}$ (3-day incubation) and $1000 \mu \mathrm{g} / \mathrm{mL}$ (5-day incubation).

Conclusion: $70 \%$ ethanol extract, fractionated-70\% ethanol extract, and water extract of J. gendarussa leaves were relatively nontoxic toward MOLT-4 cells, and fractionated-70\% ethanol extract had better potentials in virucidal activities.
\end{abstract}

Keywords: Justicia gendarussa Burm.f., MOLT-4 cells, cytotoxicity, virucidal, incubation periods

\section{Introduction}

Justicia gendarussa Burm.f. (Acanthaceae) is often used as traditional medicine. Parts of the plant that are commonly used are the root and leaves. J. gendarussa leaves have several benefits, one of which is an antiviral. The results of in vitro tests, $70 \%$ ethanol extract, fractionated-70\% ethanol extract, and water extract of $J$. gendarussa leaves showed activities inhibiting HIV's reverse transcriptase enzyme (Woradulayapinij et al., 2005; Prajogo et al., 2016).

J. gendarussa leaves contain substituted aromatic amine (Chakravarty et al., 1982), flavonoid glycosides such as gendarusin A and B (Prajogo et al., 2014), and alkaloids of justidrusamides A, B, C and D (Kiren et al., 2014). The main component in the $70 \%$ ethanol extract is apigenin flavonoid glycoside called Gendarusin A (Prajogo et al., 2009). Flavonoid compounds act as a natural source of anti-HIV therapy for patients with AIDS by inhibiting HIV's reverse transcriptase (Veljkovic et al., 2007; Ko et al., 2009). Flavonoid compounds in high concentrations can be cytotoxic which causes an increase in the mitochondrial permeability, release of cytochrome c, activation of caspase, increased levels of p53 and p21, bcl-2 pressing, apoptosis induction, and the death of necrosis cell (Bolton et al., 2000; InayatHussain et al., 2001: Morin et al., 2001; Salvi et al., 2002; Shen et al., 2004; Lee et al., 2011). Alkaloid compounds are toxic to humans, but most of them have physiological activities that are prominent and can be widely used in the treatment (Harborne, 1987).

A cytotoxicity study of the $J$. gendarussa leaves extract was conducted to ensure the safety. Cytotoxicity of $70 \%$ ethanol extract and fractionated-70\% ethanol extracton MOLT-4 cells with 3-day incubation using colorimetric methods with reagent WST-1 showed relatively non-toxic results with $\mathrm{CC}_{50}>41 \mu \mathrm{g} / \mathrm{mL}$ (Widiyanti et al., 2016). 
Studies on antiviral activities of $J$. gendarussa leaves extract and water extract of $J$. gendarussa leaves have shown their potential as an anti-HIV. 70\% ethanol extract of $J$. gendarussa leaves demonstrated anti-HIV activities by decreasing the amount of p24 antigen and holding back both syncytium formation and reverse transcriptase enzyme (Prajogo et al., 2016; Widiyanti et al., 2016). Water extract of $J$. gendarussa leaves also showed the inhibition ratio of HIV-1 reverse transcriptase of more than $90 \%$, where the inhibition rate was higher than the ethanol extract (Woradulayapinij et al., 2005).

Virucidal activity test needs to be done to verify the ability of the $J$. gendarussa leaves extract in terminating the HIV-1 virus. This test is to determine the ability of the J. gendarussa leaves extract in disabling HIV particles. Test results on Justicia reptans extracts showed virucidal activities on HIV, which were related to its major components, flavonoid glycosides (Bedoya et al., 2008). Some plant substances such as tannins and phenolic are known to have virucidal effects. These substances interact with a protein of viral particles to reduce and prevent adsorption of the virus to the host cell (Singh et al., 2005).

In this research cytotoxicity assay and virucidal activity assay were conducted with varying incubation periods to determine the effect of incubation period on the cytotoxicity's potential and virucidal activities of the J. gendarussa leaves extract on MOLT-4 cells. As a result, information regarding the safety and efficacy of J. gendarussa leaves extract in its development as an anti-HIV was obtained.

\section{Materials and Methods \\ Plant}

J. gendarussa leaves were obtained from plants cultivated in the area of Pacet, Mojokerto, East Java, Indonesia. This plant was identified by the Department of Pharmacognosy and Phytochemistry, Faculty of Pharmacy, Airlangga University (voucher no. 18/H3.1.5/DT/2012).

\section{Extraction Procedure}

J. gendarussa leaves powder was divided into two groups. The first group was leaves powder acidified to release the alkaloids, and the second one group was the leaves powder that was not acidified. Then both were extracted using $70 \%$ ethanol for 3x24 hours in a macerator device, and then the filtrate from the extraction was concentrated using a rotary evaporator. The extract was dried at a temperature of $50^{\circ} \mathrm{C}$ to obtain a $70 \%$ ethanol extract $(17.4 \% \mathrm{w} / \mathrm{w})$ and fractionated-70\% ethanol extract $(6.4 \% \mathrm{w} / \mathrm{w})$ of $J$. gendarussa leaves.

Water extract $(1.8 \% \mathrm{w} / \mathrm{w})$ was obtained by blending fresh J. gendarussa leaves into cold water, and then the filtrate was collected and dried by using the freeze dry method.

\section{Alkaloid and Flavonoid Screening of J. gendarussa Leaves Extract}

Alkaloids on $70 \%$ ethanol extract, fractionated-70\% ethanol extract and water extract of $J$. gendarussa leaves were screened by using a GF254 TLC plate with chloroform mobile phase: methanol (9:1), with staining using Dragendorff reagent. The alkaloid test results will be positive if there are orange stains.

Flavonoids on $70 \%$ ethanol extract, fractionated-70\% ethanol extract and water extract of J. gendarussa leaves were screened by using GF254 TLC stationary phase with a mobile phase of butanol-glacial acetic acid-water (4: 1: 5), with staining using citric borate. Flavonoid test results will be positive if there are yellow-green fluorescent stains using UV 366 nm (Indonesia, 2008).

\section{Materials}

$70 \%$ Ethanol pharmaceutical grade, Methanol pro HPLC (Merck), sterile water for injection, distilled water (pure water) obtained from Lab CRC-EIRD, ITD Surabaya, RPMI-1640 medium (Gibco), sodium bicarbonate (Merck), Fetal Bovine Serum (FBS) (Gibco) inactivated at a temperature of $56^{\circ} \mathrm{C}$ for 30 minutes, reagent 4-[3-(4-Iodophenyl)-2(4-nitrophenyl)-2H-5-tetrazolio]-1,3-benzene Disulfonate (WST-1) (Roche), dimethyl sulfoxide (DMSO) (Sigma), 0.2 $\mu \mathrm{m}$ nitrocellulose membrane filter (Whatman), and Zidovudine+Lamivudine / ZDV+3TC (Duviral ${ }^{\circledR}$ ).

\section{Cells and Viruses}

Cell line MOLT-4 clone 8 (Human T lymphocyte cancer cell line) and HIV isolates from a seropositive HIV donor that labeled IDU-18 were obtained from the Institute of Tropical Disease (ITD) laboratory, Airlangga University, Surabaya, Indonesia. MOLT-4 cells were cultured in RPMI-1640 media and equipped with 10\% FBS. Cells were maintained in $\mathrm{CCF} \mathrm{T}_{25}$ at a temperature of $37^{\circ} \mathrm{C}$ in $5 \% \mathrm{CO} 2$ incubator.

\section{Cytotoxicity Assay}

Cytotoxicity from the extract on MOLT-4 cells was tested by a colorimetric method using a WST-1 reagent (Kangro and Mahy, 1996). In short, $50 \mu \mathrm{L}$ of MOLT-4 cells at a concentration of $2 \times 10^{5}$ cells/well on a plate in each 
well in a 96-well microplate. Then, $50 \mu \mathrm{L}$ of each test solution with varying concentrations $(31.25 ; 62.5 ; 125 ; 250 ; 500$; and $1000 \mu \mathrm{g} / \mathrm{mL}$ ) was added to each well and incubated for 3 days and 5 days at $37^{\circ} \mathrm{C}$ in $5 \% \mathrm{CO} 2$ incubator. ZDV+3TC was used as a positive control. Control cells without treatment and control of the media were also tested. The total volume per well was $100 \mu \mathrm{L}$. After incubation, $10 \mu \mathrm{L}$ WST-1reagent was added into each of the wells and incubated for 2 hours at $37^{\circ} \mathrm{C}$ in $5 \% \mathrm{CO} 2$ incubator. Absorbance was measured at a wavelength of $450 \mathrm{~nm}$ by using a microplate absorbance reader (Bio-Rad). The high absorbance read indicated the great amount of formazan formed, illustrating that the living cells are highly capable of metabolizing WST-1salt. The percentage of cell viability was determined by the following formula:

$$
\text { Cell Viability }(\%)=\frac{\text { treatment absorbance }- \text { media control absorbance }}{\text { cell control absorbance }- \text { media control absorbance }}
$$

\section{Virucidal Test}

Virucidal activity testing on the $J$. Gendarussa leaves extract was determined by measuring the inhibitory activity against the formation of the syncytium (Kangro and Mahy, 1996; Tello et al., 2012). In short, 96-well microplates were filled with $100 \mu \mathrm{L}$ growth culture medium into each well (except for row A). $200 \mu \mathrm{L}$ of test solution with a concentration of $1000 \mu \mathrm{g} / \mathrm{mL}$ was added into row A (except the negative control column). Each test treatment group and negative control (without test solution) was done by applying two replications. Dilution was conducted to obtain various concentrations. Then, $50 \mu \mathrm{L}$ of HIV with a concentration $2 \times 10^{4}$ cells $/ \mathrm{mL}$ was added to each well containing the test solution. Then, the microplates were put in a $5 \% \mathrm{CO} 2$ incubator at a temperature of $37^{\circ} \mathrm{C}$ and incubated for 30 minutes. After the incubation, 96-well microplates were removed from the incubator, and $50 \mu \mathrm{L}$ of cells MOLT-4 with a concentration $4 \times 10^{5}$ cells $/ \mathrm{mL}$ was added to each well. Cytopathic effect was observed on days 3 and 5. The cytopathic effect, the formation of the syncytium, the virus with and without the J. gendarussa leaves extract were compared. The inhibition percentage of syncytium formation was calculated by using the following formula:

$$
\text { Syncytia Inhibition }(\%)=100-\frac{\text { total number of syncytia in the cells with test samples }}{\text { total number of syncytia in the negative control }} \times 100 \%
$$

\section{Statistical Analysis}

Data analyzed by using probit regression analysis used Minitab 17 program to calculate the value of $50 \%$ cytotoxicity concentration $\left(\mathrm{CC}_{50}\right)$, namely the concentration that could lower $50 \%$ of cell viability.

\section{Results}

Results of screening by TLC (Table 1) alkaloid showed orange stains in $70 \%$ ethanol extract and water extract of $J$. gendarussa leaves, indicating that they contained alkaloids. At the flavonoid screening results, greenish yellow fluorescence stains were found in $70 \%$ ethanol extract, fractionated-70\% ethanol extract and water extract of $J$. gendarussa leaves, indicating that they contained flavonoids.

Table 1: Alkaloid and flavonoid screening of J. gendarussa leaves extract

\begin{tabular}{|l|c|c|}
\hline \multicolumn{1}{|c|}{ Extract } & Alkaloid & Flavonoid \\
\hline $70 \%$ ethanol extract & + & + \\
\hline Fractionated-70\% ethanol extract & - & + \\
\hline Water extract & + & + \\
\hline
\end{tabular}

(+) Detected; (-) Not Detected

Cytotoxicity test results showed that the $J$. gendarussa leaves extract had low cytotoxicity in the MOLT-4 cells both after 3-day and 5-day incubations. The increase of concentrations of each ethanol extract of J. gendarussa leaves could lower the percentage of MOLT-4 cell viability (Table 2). 
Table 2: Results of cytotoxicity assay in MOLT-4 cell culture after 3 and 5day incubations

\begin{tabular}{|c|c|c|c|c|c|c|c|c|}
\hline \multirow{2}{*}{$\begin{array}{c}\text { Concentration } \\
(\boldsymbol{\mu g} / \mathbf{m L})\end{array}$} & \multicolumn{9}{|c|}{ EE } & \multicolumn{2}{|c|}{ FEE } & \multicolumn{2}{c|}{ WE } & \multicolumn{2}{c|}{ ZDV+3TC } \\
\cline { 2 - 9 } & $\mathbf{3 ~ d a y s}$ & $\mathbf{5}$ days & 3 days & $\mathbf{5}$ days & 3 days & $\mathbf{5}$ days & 3 days & $\mathbf{5}$ days \\
\hline $\mathbf{1 0 0 0}$ & 59.680 & 51.597 & 79.135 & 64.742 & 67.293 & 67.293 & 91.259 & 91.259 \\
\hline $\mathbf{5 0 0}$ & 59.962 & 55.528 & 81.579 & 67.813 & 70.771 & 70.771 & 91.447 & 91.447 \\
\hline $\mathbf{2 5 0}$ & 73.120 & 63.514 & 84.586 & 68.305 & 78.477 & 78.477 & 91.823 & 91.823 \\
\hline $\mathbf{1 2 5}$ & 74.342 & 66.339 & 86.936 & 69.656 & 79.793 & 79.793 & 94.549 & 94.549 \\
\hline $\mathbf{6 2 . 5}$ & 76.410 & 70.147 & 89.944 & 74.447 & 84.586 & 84.586 & 95.019 & 95.019 \\
\hline $\mathbf{3 1 . 2 5}$ & 78.853 & 76.781 & 90.320 & 76.781 & 88.346 & 88.346 & 97.086 & 97.086 \\
\hline
\end{tabular}

EE: $70 \%$ ethanol extract of $J$. gendarussa leaves; FEE: fractionated-70\% ethanol extract of J. gendarussa leaves; WE: Water extract of $J$. gendarussa leaves; ZDV/3TC: Zidovudine-Lamivudine

The percentage of cell viability was then used to determine the values of $\mathrm{CC}_{50}$ of each test material. $\mathrm{CC}_{50}$ values were calculated by probit regression analysis using Minitab 17 software. The $\mathrm{CC}_{50}$ value was presented in Table 3.

Table 3: $\mathrm{CC}_{50}$ in MOLT-4 cell culture after 3 and 5day incubations

\begin{tabular}{|l|r|r|}
\hline \multicolumn{2}{|c|}{ Extract } & \multicolumn{2}{|c|}{$\mathbf{C C}_{\mathbf{5 0}}(\boldsymbol{\mu \mathbf { g }} / \mathbf{m L} \mathbf{L})$} \\
\cline { 2 - 3 } & 3day incubation & 5day incubation \\
\hline 70\% ethanol extract & 3928.620 & 3176.581 \\
\hline Fractionated-70\% ethanol extract & 81782.428 & 12175.870 \\
\hline Water extract & 16372.689 & 2946.117 \\
\hline ZDV+3TC & 1154489.530 & 462711.187 \\
\hline
\end{tabular}

The test results of virucidal activities (Table 4) were calculatedby the inhibition percentage of syncytium formation performed at various concentrations. Table 4 shows that the increase of the concentration of J. gendarussa leaves extract was able to increasec the inhibition percentage of syncytium formation in MOLT-4 cells infected with HIV.

Table 4:Test results of inhibition of syncytium formation in MOLT-4 cell culture after 3 and 5 day incubations

\begin{tabular}{|c|c|c|c|c|c|c|c|c|}
\hline \multirow{2}{*}{$\begin{array}{c}\text { Concentration } \\
(\boldsymbol{\mu g} / \mathbf{m L})\end{array}$} & \multicolumn{9}{|c|}{ EEncytia Inhibition (\%) } \\
\cline { 2 - 10 } & $\mathbf{3}$ & \multicolumn{2}{|c|}{ FEE } & \multicolumn{3}{c|}{ WE } & \multicolumn{3}{c|}{ ZDV+3TC } \\
\cline { 2 - 10 } & $\mathbf{3 ~ d a y s}$ & $\mathbf{5}$ days & $\mathbf{3}$ days & $\mathbf{5}$ days & $\mathbf{3}$ days & $\mathbf{5}$ days & 3 days & $\mathbf{5}$ days \\
\hline $\mathbf{1 0 0 0}$ & 100 & cd & 96.534 & 91.497 & 68.803 & cd & 97.479 & 94.485 \\
\hline $\mathbf{5 0 0}$ & 100 & cd & 96.218 & 88.510 & 48.004 & 56.798 & 96.218 & 91.497 \\
\hline $\mathbf{2 5 0}$ & 95.903 & 91.727 & 94.958 & 85.063 & 15.231 & 22.788 & 95.903 & 81.386 \\
\hline $\mathbf{1 2 5}$ & 13.341 & 31.750 & 49.895 & 52.202 & 9.559 & 22.328 & 92.437 & 78.169 \\
\hline $\mathbf{6 2 . 5}$ & 7.983 & 30.142 & 44.223 & 47.376 & 10.820 & 11.528 & 91.807 & 80.927 \\
\hline $\mathbf{3 1 . 2 5}$ & 10.820 & 2.566 & 39.181 & 38.874 & 4.517 & 3.485 & 94.643 & 60.245 \\
\hline
\end{tabular}

EE: $70 \%$ ethanol extract of $J$. gendarussa leaves; FEE: fractionated-70\% ethanol extract of J. gendarussa leaves; WE: Water extract of $J$. gendarussa leaves; ZDV/3TC: Zidovudine-Lamivudine; cd: cell death

\section{Discussion}

Cytotoxicity assay with the variations of incubation periods was performed to determine the effect of incubation periods on the cytotoxicity potentials of $J$. gendarussa leaves extract on MOLT-4 cells. Cytotoxicity assay is the colorimetric method using a tetrazolium salt reagent 4-[3-(4-Iodophenyl)-2-(4-nitrophenyl)-2H-5-tetrazolio]-1,3benzene Disulfonate or better known as the WST-1 assay. The test is based on the reduction of the WST-1 by living cells that produce soluble formazan salt (Rode, 2008). The great amount of formazan formed reflects the high cell viability, namely the number of active living cells metabolizing WST-1 (Rampersad, 2012).

The observation of cytotoxic activities was done by calculating the percentage of MOLT-4 cell viability, and then a regression equation between the percentage of cell viability with log concentration was made. The number of cytotoxicity activities of the extract was determined by the $\mathrm{CC}_{50}$ values in which the concentration of the extract was able to lower $50 \%$ of cell viability. 
The extract cytotoxicity level was evaluated based on the $\mathrm{CC}_{50}$ values. $\mathrm{CC}_{50}$ values below $20 \mu \mathrm{g} / \mathrm{mL}$ would mean cytotoxic; $\mathrm{CC}_{50}$ values ranging between $21-40 \mu \mathrm{g} / \mathrm{mL}$ would mean low cytotoxic; $\mathrm{CC}_{50}$ values of more than 41 $\mu \mathrm{g} / \mathrm{mL}$ would mean non-cytotoxic (Mohamed et al., 2000; Rohaya et al., 2005; Ayob et al., 2013). In this study, observation cytotoxic activity was observed on different days, namely on day 3 and 5, because previous studies have reported that there was a significant difference from the values of $\mathrm{CC}_{50}$ when calculated on different days (Kimura $e t$ al., 1999).

A calculation used the probit regression analysis showed that the values of CC50 in MOLT-4 cell culture by incubation period of 3 and 5 days with the test materials $70 \%$ ethanol extract, fractionated-70\% ethanol extract, and water extract of $J$. gendarussa leaves demonstrated that all $J$. gendarussa leaves extract showed non-cytotoxic activities in MOLT-4 cells because of the values of CC50> $41 \mu \mathrm{g} / \mathrm{mL}$ (Table 3). Previous research on the cytotoxic activities of $70 \%$ ethanol extract and fractionated-70\% ethanol extract of $J$. gendarussa leaves on MOLT-4 cells by an incubation period of 3 days using the WST-1 colorimetric method stated that CC50 values obtained from the two extracts also indicated non-toxicity (Widiyanti et al., 2016).

The differences CC50 values between incubation 3 and 5 days were probably due to the compounds of both extracts. The content of alkaloids probably gave a major influence on the cell death when compared to the content of flavonoids in the extracts (Astuti et al., 2006). CC50 values of 70\% ethanol extract and water extract were lower than fractionated-70\% ethanol extract. This is because the $70 \%$ ethanol extract and water extract did not release the alkaloids, which means that the extracts contained a high level of alkaloids (Table 1). Therefore, it gave an effect on MOLT-4 cell death.

The viability of cells in MOLT-4 cell culture showed a decline along with the increase in the concentration of $70 \%$ ethanol extract, fractionated-70\% ethanol extract, and water extract of $J$. gendarussa leaves. A decrease in cell viability means that there was an inhibition of cell growth associated with suppression of cell proliferation activities so that the number of dividing cells or the living ones declined. Various activities of cell signaling that involved protein expression on programmed cell death such as bid, bax and bcl-2 were likely to be activated when the cell line was exposed to the active compound contained in the extracts (Singh, 2014). An assay using tetrazolium could only detect the formation of formazan (related to the activity of mitochondria of living cells) but not determine the cause of cell death (Paul and Manjula, 2014).

In this study, virucidal activities were also tested with the inhibition parameters of syncytium formation (Table 4). The test materials are considered to have virucidal activities if they inhibit the formation of syncytium $\geq 90 \%$ (Tello et al., 2012). Based on the calculation of the inhibition percentage of syncytium formation in MOLT-4 cultured cells on day 3 , test materials that inhibited the formation of syncytium were $\geq 90 \%$ in $70 \%$ ethanol extract of $J$. gendarussa leaves at a concentration of $250 \mu \mathrm{g} / \mathrm{mL}, 500 \mu \mathrm{g} / \mathrm{mL}$, and $1000 \mu \mathrm{g} / \mathrm{mL}$; fractionated-70\% ethanol extract of $J$. gendarussa leaves at a concentration of $250 \mu \mathrm{g} / \mathrm{mL}, 500 \mu \mathrm{g} / \mathrm{mL}$ and $1000 \mu \mathrm{g} / \mathrm{mL}$; and ZDV+3TC at a concentration of $31.25 \mu \mathrm{g} / \mathrm{mL}, 62.5 \mu \mathrm{g} / \mathrm{mL}, 125 \mu \mathrm{g} / \mathrm{mL}, 250 \mu \mathrm{g} / \mathrm{mL}, 500 \mu \mathrm{g} / \mathrm{mL}$, and $1000 \mu \mathrm{g} / \mathrm{mL}$. Meanwhile, from the inhibition percentage of syncytium in MOLT-4 cell culture onday 5, it was found that test materials inhibiting the formation of syncytium were $\geq 90 \%$ in $70 \%$ ethanol extract of $J$. gendarussa leaves at a concentration of $250 \mu \mathrm{g} / \mathrm{mL}$; fractionated$70 \%$ ethanol extract of $J$. gendarussa leaves at a concentration of $1000 \mu \mathrm{g} / \mathrm{mL}$; and ZDV+3TC at a concentration of $500 \mu \mathrm{g} / \mathrm{mL}$ and $1000 \mu \mathrm{g} / \mathrm{mL}$.

Virucidal activity test results showed that the fractionated-70\% ethanol extract had better potentials in virucidal activities than other extracts. In fact, $70 \%$ ethanol extract of $J$. gendarussa leaves also have the potentials, but it caused death in MOLT-4 cells at the concentration of $500 \mu \mathrm{g} / \mathrm{mL}$ and $1000 \mu \mathrm{g} / \mathrm{mL}$ on day 5 of incubation. Cell death also occurred in the water extract of J. gendarussa leaves at a concentration of $1000 \mu \mathrm{g} / \mathrm{mL}$. This is likely due to the alkaloid content in $70 \%$ ethanol extract and water extract of $J$. gendarussa leaves (Table 1 ).

Differences in virucidal activities from each test material were because each of the test materials has different chemical contents that could inhibit the development phase of the virus differently, such as the stage of viral entry until the stage of replication (Leteane et al., 2012). In J. gendarussa leaves extract, without alkaloids, the extracts were capable of providing anti-HIV activities better and lowered the cellular toxicity, compared to the extracts containing alkaloids.

\section{Conclusion}

The results obtained showed that $70 \%$ ethanol extract, fractionated-70\% ethanol extract and water extract of $J$. gendarussa leaves were relatively nontoxic toward MOLT-4 cells after 3 and 5 days incubation. The results of the virucidal activity test showed that fractionated-70\% ethanol extract had better potentials in virucidal activities than other extracts.

Conflicts of Interest: The authors declare no conflict of interest.

Acknowledgement: The authors would like to thank the Collaborative Research Center for Emerging and Reemerging Infectious Disease (CRC-ERID), Institute of Tropical Disease (ITD), Airlangga University for supporting Biosafety Level-3 facility. 


\section{References}

1. Astuti, E., Pranowo, D. and Puspitasari, S. D. (2006). Cytotoxicity of Phaleria macrocarpa (Scheff.) Boerl. Fruit Meat And Seed Ethanol Extract to Mononuclear Perifer Normal Cell Of Human Body. Indonesian Journal of Chemistry, 6(2): 212-218.

2. Ayob, Z., Samad, AA., and Bohari, SPM. (2013). Cytotoxicity Activities in Local Justicia gendarussa Crude Extracts against Human Cell Lines. Jurnal Teknologi (Sciences and Engineering), 64(2): 45-52.

3. Bedoya L.M., Alvarez A., Bermejo M., Gonza'lez N., Beltra'n M., Sa’́nchez-Palomino S., Cruz S.M., Gaitán I., Olmo E., Escarcena R., Garcı'a P.A., Ca'ceres A., Feliciano A.S., Alcamı J. (2008). Guatemalan plants extracts as virucides against HIV-1 infection.Phytomedicine. Elsevier, 15(6): 520-524.

4. Bolton, JL., Trush, MA., Penning, TM., Dryhurst, G., and Monks, TJ . (2000). Role of Quinones in Toxicology. Chemical research in toxicology. American Chemical Society (ACS) Publications,13: 135-160.

5. Chakravarty, A. K., Dastidar, P. P. G. and Pakrashi, S. C. (1982). Simple Aromatic Amines from Justicia gendarussa. 13C NMR Spectra of the Bases and Their Analogues. Tetrahedron. Elsevier, 38(12): 1797-1802.

6. Harborne, J. B. (1987). Metode Fitokimia Penuntun Cara Modern Menganalisis Tumbuhan, Terbitan Kedua (in Indonesian). Institut Teknologi Bandung.

7. Inayat-Hussain, SH., Winski, SL., and Ross, D. (2001). Different Involvement of Caspase in Hydroquinone-induced Apoptosis in Human Leucemic HL-60 and Jurcat Cells. Toxicology and applied pharmacology. Elsevier, 175(2): 95103.

8. Indonesia, D. K. R. (2008). Farmakope Herbal Indonesia, Edisi I (in Indonesian). Jakarta: Departemen Kesehatan RI, : 78-80.

9. Kangro, H. O. and Mahy, B. W. J. (1996). Virology Methods Manual. Academic Press, pp. 293-308.

10. Kimura, E., Koike, T. and Inouye, Y. (1999). Macrocyclic Polyamines and Their Metal Complexes: A Novel Type of Anti-HIV Agent. Perspective on Bioinorganic Chemistry, 4: 145-164.

11. Kiren, Y., Deguchi, J., Hirasawa, Y., Morita, H., and Prajogo, B. (2014). Justidrusamides A-D, New 2-aminobenzyl Alcohol Derivatives from Justicia gendarussa. Journal of Natural Medicines. Springer, 68(4): 754-758.

12. Ko, Y-J., Oh, H-J., Ahn, H-M., Kang, H-J., Kim, J-H., and Ko, YH. (2009). Flavonoids as Potential Inhibitors of Retroviral Enzymes. Journal of the Korean Society for Applied Biological Chemistry. Springer, 52(4): 321-326.

13. Lee, MH., Dan, DW., Hyon, SH., and Park, JC. (2011). Apoptosis of Human Fibrosarcoma HT-1080 Cell by Epigallocathecin-3-O-gallate via induction of p53 and Caspase as well as Suppression of Bcl-2 and Phosphorylated Nuclear Factor- $\kappa$ B. Apoptosis. Springer, 16(1): 75-85.

14. Leteane, MM., Ngwenya, BN., Muzila, M., Namushe, A., Mwinga, J., Musonda, R., Moyo, S., Mengestu, YB., Abegaz, BM., and Andrae-Marobela, K. (2012). Old Plants Newly Discovered: Cassia sieberiana D.C. and Cassia abbreviate Oliv. Root Extract Inhibit in Vitro HIV-1c Replication in Peripheral Blood Mononuclear Cells (PBMCs) by Different Modes of Actions. Journal of Ethnopharmacology. Elsevier, 141(1): 48-56.

15. Mohamed, SM., Ali, AM., Rahmani, M., Dhaliwal, JS., and Yusoff, K. (2000). Apoptotic and Neurotic Cell death Manifestations in Leukemic Cell treated with Methylgerambulin a Sulphone from Glycosmis calcicola. Journal Biochemistry Molecular Biology and Biopsychology. Harwood Academic Publishers, 4(4): 253-26.

16. Morin, D., Barthelemy, S,. Zini, R., Labidalle, S., and Tillement, JP. (2001). Curcumin Induces the Mitochondrial Permeability Transition Pore by Membrane Protein Thiol Oxidation. Federation of European Biochemical Societies (FEBS) letters. Wiley Online Library, 495(1-2): 131-136.

17. Paul, A. and Manjula. (2014). Cytotoxic and Antiproliferative Activity of Indian Medicinal Plant in Cancer Cell. International Journal of Science and Research, 3(6): 88-93.

18. Prajogo, B. (2014). Autentik Tanaman Justicia gendarussa Burm.f. Sebagai Bahan Baku Obat Kontrasepsi Pria (in Indonesian). Surabaya: Airlangga University Press.

19. Prajogo, B., Guliet, D., Queiroz, F, Wolfernder, J-L., Cholies, N., Aucky, H., and Hostettmann, K. (2009). Isolation of Male Antifertility Compound in n-Butanol Fraction of Justicia gendarussa Burm.f. Leaves. Folia Medica Indonesiana, 45(1):28-31.

20. Prajogo, B., Widiyanti, P. and Riza, H. (2016). Effect Of Free Alkaloid And Non-Free Alkaloid Ethanol 70\% Extract of Justicia gendarussa Burm.f.. Leaves Against Reverse Transcriptase HIV Enzyme In Vitro And Chemical Compound Analysis. Indonesian Journal of Tropical and Infectious Disease, 6(1): 1-4.

21. Rampersad, S. N. (2012). Multiple applications of Alamar Blue as an indicator of metabolic function and cellular health in cell viability bioassays. Sensors. Molecular Diversity Preservation International, 12(9): 12347-12360.

22. Rode, H. J. (2008). Apoptosis, Cytotoxicity and Cell Proliferation. Roche Diagnostics GmbH, 4: 116-135.

23. Rohaya, Abdul Manaf, Daud, Nor Hadiani, Khozirah, and Nordin. (2005). Antioxidant, Radical-Scavenging, Antiinflammatory, Cytotoxic and Antibacterial Activities of Methanolic Extracts of Some Hedyotis Species. Life Sciences. Elsevier, 76(17): 1953-1964.

24. Salvi, M., Brunati, AM., Clari, G., and Toninello, A. (2002). Interaction of Genistein with the Mitochondrial Electron Transport Chain Results in the Opening of the Membrane Transition Pore. Biochimica et Biophysica Acta (BBA)Bioenergetics. Elsevier, 1556: 187-196.

25. Shen, SC., Ko, CH., Tseng, SW., Tsai, SH., and Chen, YC. (2004). Structurally Related Antitumor Effects of Flavanones in vitro and in vivo: Involvement of Caspase 3 Activation, p21 Gene Expression, and Reactive Oxygen Species Production. Toxicology and Applied Pharmacology. Elsevier, 197(2): 84-95. 
26. Singh, IP., Bharate, SB., and Bhutani, KK. (2005). Anti-HIV Natural Products. Current Science. Journal Storage (JSTOR), 89(2): 269-290.

27. Singh, R. 2014. Interaction and Cytotoxicity of Compounds with Human Cell Lines. Romanian Journal of Biochemistry, 51(1): 57-74.

28. Veljkovic, V., Mouscadet, J-F., Veljkovic, N., Glisic, S., and Debyser, Z. (2007). Simple Criterion for Selection of Flavonoid Compounds With Anti-HIV Activity. Bioorganic and Medicinal Chemistry Letters. Elsevier, 17(5): 12261232.

29. Widiyanti, P., Prajogo, B. and Hikmawati, N. P. E. (2016). Cytotoxicity of Justicia gendarussa Burm.f. Leaf Extracts on MOLT-4 Cell. Indonesian Journal of Tropical and Infectious Disease, 6(1): 24-28. 